\title{
Adenovirus serotype 26 utilizes CD46 as primary cellular receptor and only transiently activates T lymphocytes following vaccination of rhesus monkeys
}

\author{
H Li ${ }^{1 *}$, EG Rhee ${ }^{1}$, K Masek-Hammerman $^{2}$, JE Teigler ${ }^{1}$, P Abbink${ }^{1}$, DH Barouch ${ }^{1}$
}

From AIDS Vaccine 2012

Boston, MA, USA. 9-12 September 2012

\section{Background}

Adenovirus serotype 5 (Ad5) utilizes coxsackievirus and adenovirus receptor (CAR) as its primary cellular receptor. However, the cellular receptor utilized by Ad26 and the inflammatory responses elicited following Ad26 vaccination remain unclear.

\section{Methods}

Receptor usage was assessed using CD46 transgenic mouse cells, as well as by CAR- and CD46-specific mAb blocking studies using human PBMC. Twelve adult rhesus monkeys were inoculated with of $10^{11}$ viral particles (vp) of replication-competent $\operatorname{Ad} 5$ and $\operatorname{Ad} 26(\mathrm{~N}=6)$ or saline $(\mathrm{N}=6)$ at weeks -8 and -4 , and were vaccinated intramuscularly with $3 \times 10^{10}$ vp replication-incompetent Ad26-Gag/Pol/Env vectors. At week 2, monkeys were sacrificed to assess immunologic and inflammatory responses at mucosal surfaces.

\section{Results}

Transduction by Ad26 and Ad35 vectors was markedly enhanced in CD46 transgenic mouse cells compared with wild type mouse cells. Moreover, transduction of human PBMC by Ad26 and Ad35 vectors was efficiently blocked by the anti-CD46 mAbs 13/42, M177 and MEM-258, but not by the anti-CAR mAbs RmcB and E1-1. Monkeys with and without baseline Ad5/Ad26 immunity exhibited similar magnitude and only transient activation (1-2 weeks) of vector-specific $\mathrm{CD} 4^{+} \mathrm{T}$ cell responses in both PBMC and colorectal biopsies.
Inflammatory cell infiltrates in colorectal and foreskin mucosa were comparable in baseline and vaccinated animals regardless of baseline Ad5/Ad26 immunity.

\section{Conclusion}

Ad26 utilizes CD46 and not CAR as a primary cellular receptor for infection. We also observed no increased mucosal cellular activation or vector-specific $\mathrm{CD} 4^{+}$ T lymphocytes in baseline Ad5/Ad26-seropositive monkeys as compared with baseline seronegative monkeys following Ad26 vaccination. These data contribute to our understanding of the biology of $\operatorname{Ad} 26$ as a candidate vaccine vector.

\section{Author details}

${ }^{1}$ Beth Israel Deaconess Medical Center, Boston, MA, USA. ${ }^{2}$ New England Primate Research Center, Southborough, MA, USA.

Published: 13 September 2012

doi:10.1186/1742-4690-9-S2-069

Cite this article as: Li et al:: Adenovirus serotype 26 utilizes CD46 as primary cellular receptor and only transiently activates T lymphocytes following vaccination of rhesus monkeys. Retrovirology 2012 9(Suppl 2):O69.

${ }^{1}$ Beth Israel Deaconess Medical Center, Boston, MA, USA

Full list of author information is available at the end of the article

(C) $2012 \mathrm{Li}$ et al; licensee BioMed Central Ltd. This is an Open Access article distributed under the terms of the Creative Commons Attribution License (http://creativecommons.org/licenses/by/2.0), which permits unrestricted use, distribution, and reproduction in any medium, provided the original work is properly cited. 